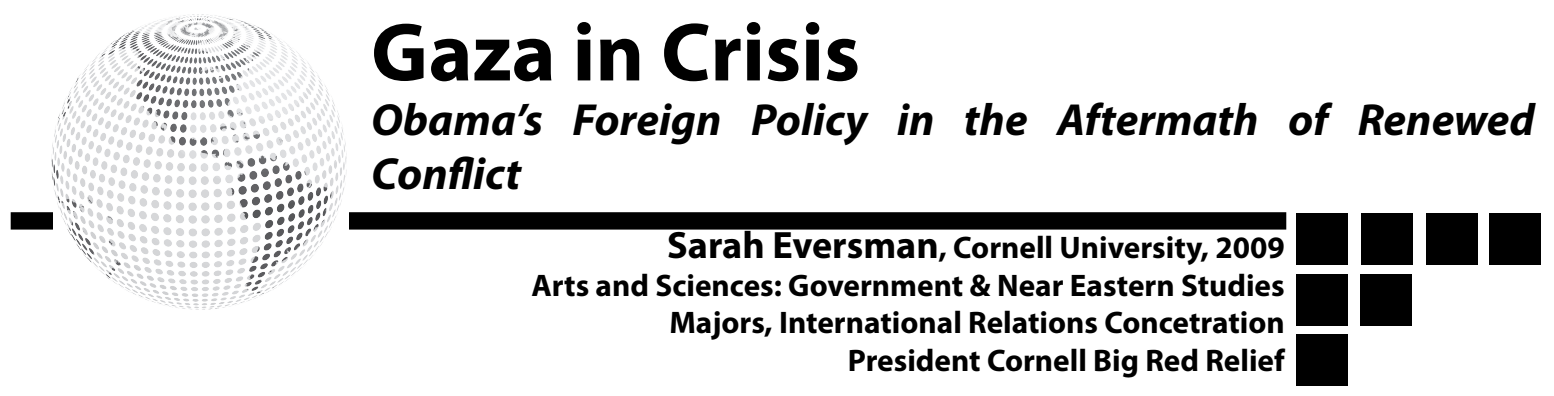

This ongoing dispute clearly concerns the United States, the long-term third party in peace negotiations, and a close ally of Israel. However, now more than ever European and Middle Eastern states are invested in the resolution of this conflict. The stability of Israel and the humanitarian status of the Palestinians depend upon the resolution of this conflict. So, what should President Barack Obama hope to accomplish in the coming months, in light of the overwhelming array of issues already on his agenda? And what should the rest of the world expect from U.S. foreign policy regarding the Israeli-Palestinian conflict under Mr. Obama's administration?

Political maneuvering is already underway and the recent elections in Israel have shifted the power structure of Israeli politics significantly to the right with Benjamin Netanyahu, leader of the right-wing Likud Party, elected as Prime Minister and sworn in at the end of March 2009. Furthermore, Egyptian negotiators are attempting to bridge the deep divide between Fatah and Hamas in order to strengthen the unity of Palestinian politics, but the outcome of this endeavor remains to be seen. As the global economic crisis continues to worsen, the attention of the world shifted from the IsraeliPalestinian conflict to the G-20 Summit and NATO meetings. Therefore, it is the role of world leaders, particularly the United States, to maintain focus on rebuilding Gaza and acting as intermediaries in any Israeli and Palestinian negotiations. Secretary of State Hillary Clinton must ensure the State Department keeps its finger firmly on the pulse of political and social activities in the region in order to prevent renewed fighting.

The United States and Europe should have anticipated more aware of this impending crisis and in the aftermath of the conflict, neither can afford to watch from the sidelines. Dialogue and diplomacy are the way out of this mess, and it is in the interests of both Europe and the U.S. to engage both sides in this dispute if further violence is to be prevented. If Mr. Obama wants to have peace in the Middle East in our time, he will have to persuade all of the actors to sit around a table and to talk about the conflict. The Bush administration's strategy of strengthening Fatah and isolating Hamas has not worked. Secret negotiations are just as ineffectual as the exclusion of certain actors. Only a common platform for dialogue will enable the U.S. and the European Union to fulfill their peacemaking mission.

\section{Timeline of the Crisis}

The Israeli operation began with an intense bombardment of the Gaza Strip targeting Hamas bases, police headquarters and offices, but also more controversially civilian infrastructure including mosques, houses, schools, and medical facilities. Israel claimed many of these buildings were being used by combatants, and as storage spaces for weaponry. Hamas retaliated with attacks on southern Israel, reaching previously untargeted cities such as Beersheba and Ashdod. By the time Israel began its ground invasion into the Gaza Strip on January 3, 2009, 3 Israeli civilians were killed by Palestinian rocket attacks and hundreds of Gazans had been reported killed by Israeli air strikes and rocket fire. These numbers continued to escalate while the humanitarian situation in Gaza rapidly deteriorated.

Many called for an immediate ceasefire and raised valid concerns about the humanitarian repercussions in the Gaza Strip. United Nations Secretary General Ban Ki-Moon 
literally pleaded for an end to the violence saying, "My message is simple, direct and to the point: the fighting must stop. In Gaza, the very foundation of society is being destroyed: people's homes, civic infrastructure, public health facilities and schools." ${ }^{1}$ The United Nations issued Security Council Resolution 1860 that called for "an immediate ceasefire in Gaza leading to a full Israeli withdrawal, unimpeded provision through Gaza of food, fuel and medical treatment, and intensified international arrangements to prevent arms and ammunition smuggling." ${ }^{2}$ All members stressed the importance of an "immediate and durable ceasefire." Unfortunately, the resolution was ineffective, unsuccessful and ignored by Israel and Hamas, who both continued fighting.

As of January 12 the United Nations reported 900 Palestinians killed in the Israeli offensive, and almosthalf of the 3,860 wounded, were women and children. ${ }^{3}$ Furthermore, multiple news sources reported that more than 400,000 Gazans were left without running water and around 4,000 homes had been ruined, leaving tens of thousands of people homeless. ${ }^{4}$ The conflict came to an end on January 18, 2009 after first Israel and then Hamas announced unilateral ceasefires. On January 21 , Israel completed its withdrawal from the Gaza Strip. This was exactly a day after President Obama's inauguration, highlighting the fact that the conflict took place in the remaining days of President George W. Bush's presidency and immediately before President Barack Obama's inauguration. Many analysts surmised that Israel was emboldened in its attack with the knowledge that neither Mr. Bush nor Mr. Obama could legitimately influence the Palestinian or Israeli leadership, with the former a lame duck president and the latter not officially sworn into office.

\section{The Aftermath: Political and Civilian Casualties}

On March 2, 2009 it was reported that international donors pledged $\$ 4.5$ million in

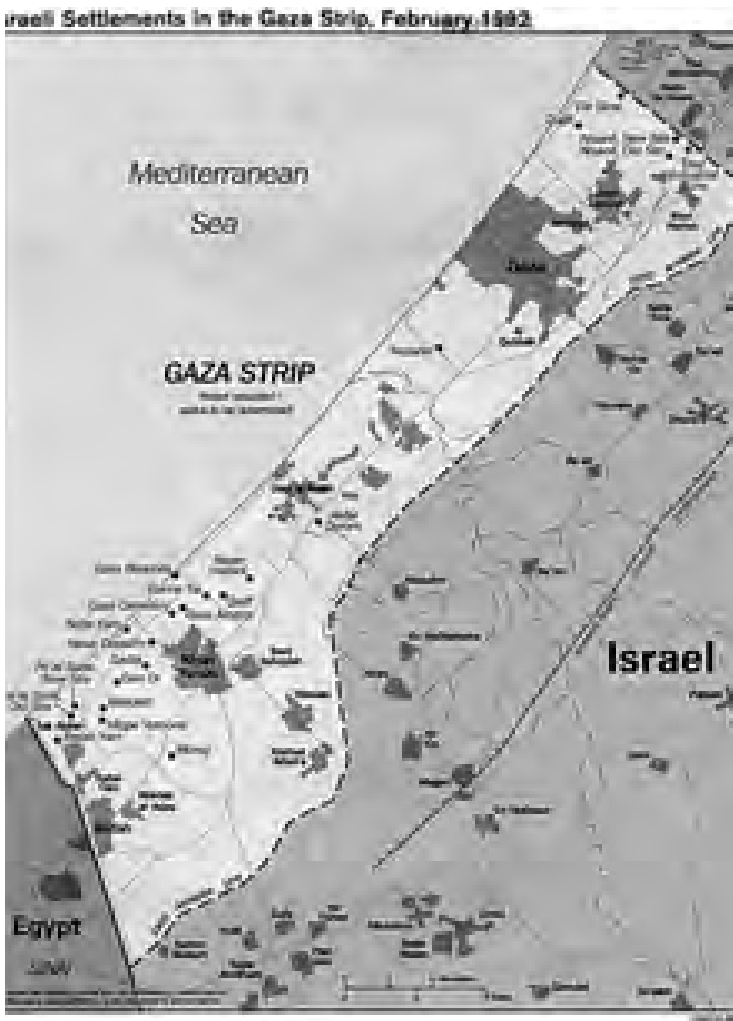

aid for the Palestinians, mainly for rebuilding Gaza after Israel's offensive. ${ }^{5}$ Financial support for Gaza's reconstruction is essential, but rebuilding Gaza is only the first step in the peace process. Improving the political situation will require much more complex and determined diplomatic efforts. If the U.S. had been more aware of the situation on the ground in Israel and Gaza prior to the conflict, it would have been more prepared for the violence to come; it cannot risk being this unprepared yet again. In the build up to the recent crisis both Israel and Hamas violated conditions of the delicate truce agreement. The six-month truce between Hamas and Israel was continually compromised by Israel's blockade on the Gaza Strip and the ongoing barrage of rocket attacks launched into southern Israeli cities by Palestinian militants in the Gaza Strip.

Since Hamas gained power in the Gaza Strip during the summer of 2007, tensions within Palestinian politics have remained high. The intense divide between the two dominant Palestinian political parties, Fatah and Hamas, has further weakened Palestinian unity and the 
ability of Fatah's moderate leader, Mahmoud Abbas, to advocate for Palestinian statehood in any negotiations with Israel and the U.S. On the center-left, Fatah, a faction of the Palestinian Liberation Organization, tentatively maintains its power in the West Bank, although the party is internally divided and tainted by charges of corruption. However, the Islamic paramilitary force of Hamas is unsupported by the U.S. and many European countries that consider the party to be a terrorist organization and an unwilling partner for peace negotiations with Israel.

Yet, the question of Hamas and its status as a terrorist organization are no longer the main focus of the debate. As Richard N. Haass, President of the Council on Foreign Relations wrote in an article in Foreign Affairs, "The way out of this dilemma is to make it clear that Hamas, and not the United States, is responsible for the Gazans' fate. The cease-fire agreement that Egypt negotiated is holding for the moment precisely because the Hamas leadership has effectively policed it, choosing to place the needs of Gazans ahead of Hamas' interest in 'resistance."' ${ }^{\prime \prime}$ The United States should encourage these diplomatic efforts and allow Egypt, Israel, and the Palestinian Authority to address their relationships with Hamas.

The Obama administration must be prepared to put pressure on its ally to prevent

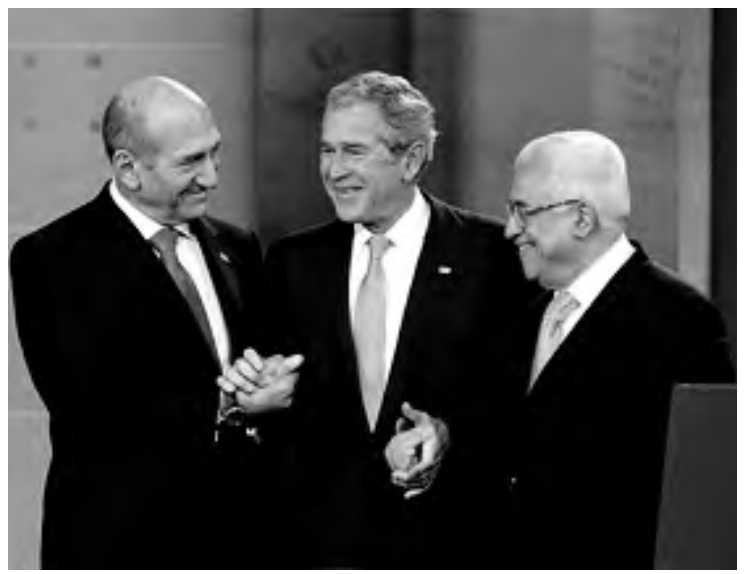

Israeli Prime Minister Ehud Omert, left, President George W. Bush, and Palestinian President Mahmoud Abbas shake hands at the Annapolis Conference, November 2008 further territorial expansion and to moderate its new far-right government; regionally, it must focus on Israel, more than Hamas or Hezbollah. Some promising steps have already been taken by the U.S. to improve Israel's relations with Syria. Mr. Obama's "outstretched" hand has already dispatched two senior officials to Syria for the first time in four years. Improved relations between Syria and Israel are critical because of the power Syria holds over Hamas and Hezbollah. In addition, a renewed strategic relationship could also affect Syria's connections with Iran. As Haass notes, "A U.S.-brokered peace between Israel and Syria would remove Damascus as an enemy and, in the process, likely cause the breakup of the Iranian-Syrian alliance." ${ }^{\prime 7}$

The strategic importance of Iran is critical to the peace process and a reality President Obama clearly acknowledges. He recently attempted to engage the Iranian people via a video message in order to signal a new U.S. approach, albeit coupled with warnings that Tehran's suspected quest for nuclear weapons and support for terrorist groups are unacceptable. Iran is highly important, as former ClA Case Officer and Middle East Specialist Robert Baer explains: "Hezbollah, Hamas, and the Shiite parties in Iraq look to Tehran for financial aid and support. As long as the U.S. does not solve the Israeli-Palestinian conflict Iran's influence will grow." ${ }^{\prime 8}$ Mr. Obama must reengage in the Arab-Israeli peace initiative and strategically engage surrounding states with an integrated approach that considers the regional dynamics. Progress on peacemaking would certainly get Iran's attention and likely cause concern in Tehran that it's bid for regional primacy was failing.

Therefore, while the framework from the Annapolis process remains in place, the Obama administration must resume negotiations and help bridge differences between the players. The inclusion of regional players, particularly Syria, Lebanon, and Jordan, would work to the U.S. advantage, 
in part because these states understand the region much better than does the United States. Furthermore, given how much time the Israelis and the Palestinians have already spent negotiating, U.S.-sponsored solutions should be proposed sooner rather than later. As long as this inaction continues, Iran, Hezbollah, and Hamas continue to benefit from the anger in the Arab street and Muslim world generated from this conflict.

Unfortunately, when it comes to finalstatus negotiations, the Obama administration will have a tough time with this new Israeli government. Some believe that present conditions are not propitious for solving the Palestinian question, and the results of the recent Israeli elections make them even less so. ${ }^{9}$ For example, Avigdor Lieberman, Israel's new foreign minister in Mr. Netanyahu's Likudled government, caused upset and surprise in his first days in office due to a blunt speech in which he declared that Israel was not obligated to continue an American-backed peace effort with the Palestinians, started at a conference in Annapolis, Maryland in late 2007. ${ }^{10}$

In light of this enflamed rhetoric it appears to many that the prospects for peace are fairly bleak. A report published by the Center for Strategic and International Studies this March states that, "This may be the Middle East that Israel and its Arab neighbors have to live with. In fact, there is little hope of a sudden return to a viable peace process.... Israel has to understand that the choice between war and peace will not always be open, and that the Arab peace initiative that is on the table today will not stay on the table."11

If the Obama administration seriously seeks to foster peace it should emphasize the importance of negotiating for a finalstatus agreement. The United States must encourage the Palestinians to crack down on terrorist activities in the territories while concurrently pressing Israel to reengage in the peace process. Before the Gaza conflict both sides took partial steps toward fulfilling their commitments made in the road map for a two- state solution proposed by the Quartet (the European Union, the UN, the United States, and Russia). However, clearly the process is stalled, and because it will take time to come to any final status agreement, the Obama administration should lay the groundwork for deploying international forces and to partner with the Palestinian forces until they can police their own territory. Many analysts, including Martin Indyk, Director of the Saban Center for Middle East Policy at the Brookings Institution, have advocated for the introduction of a peacekeeping force in the region. Indyk argues that, "The key issue is to get a force on the border between Egypt and Gaza that will prevent the smuggling of offensive weapons into Gaza that are then used by Hamas in the future to attack Israeli civilians."

Finally, Mr. Obama should seek the active involvement of Arab states in the peace process. Arab states were ready to commit to the peace process prior to the violence in Gaza. Recently, following in Saudi Arabia's footsteps, the 21 other members of the Arab League offered to sign peace agreements and normalize relations with Israel. Mr. Obama must act upon this moment, and gaining the renewed involvement of the Arab states will be easier if they see that negotiations are progressing and that the reconstruction of Gaza is underway. However, the Arab states need to be more committed to their financial pledges to the Palestinian Authority and to engage more visibly with Israel throughout the process, not just at the end. ${ }^{12}$ Perhaps Mr. Obama's new Middle East Envoy, George Mitchell, can succeed where many others have not. Mr. Obama appointed him to this post after Mitchell played a pivotal role in the Northern Ireland peace process, for which he was awarded the Presidential Medal of Freedom by President Clinton in 1999.

With the Obama administration's renewed emphasis on diplomacy and dialogue it is possible that prospects for peace between Palestinians and Israelis remain. There are many new challenges to confront including 
the hawkish Israeli leadership and the fraught divide between Hamas and Fatah. However, inaction is not an option. By combining new strategies with the Annapolis framework, Mr. Obama could improve Israeli-Syrian relations, engage the Arab states, and indirectly weaken Iran's influence on the region. With an integrated approach Mr. Obama must resume the peace process in the Middle East or be doomed to fail where so many have in the past.

\section{Bibliography}

Cordesman, Anthony. "The Gaza War: A Strategic Analysis." Center for Strategic and International Studies: Washington DC. February 2, 2009.

Gause, Gregory III. "The Return of the Old Middle East: How to Win at Balance-of-Power Politics." March 12, 2009 http://www.

foreignaffairs.com/articles/64844/f-gregory-gause-iii/the-return-of-the-old-middle-east?page=show\#

Haass, Richard and Indyk, Martin. "Beyond Iraq: A New U.S. Strategy for the Middle East." Foreign Affairs. January/February 2009.

Hanelt, Christian-Peter. "After Gaza: A Common Dialogue Platform for the Middle East." Central and Eastern

European Online Library. Spotlight Europe, Issue: 02 / 2009, pgs: 18, www.ceeol.com.

Maqbool, Aleem. "Scale of Gaza Destruction Emerges." January 19, 2009. http://news.bbc.co.uk/1/hi/world/middle_east/7836869.stm

Ravid, Barak and Shamir, Shlomo. "Israel Rejects UN Truce Resolution." Haaretz Correspondents and New

Agencies. January 10, 2009. http://www.haaretz.com/hasen/spages/1054201.html

New Israeli Foreign Minister Dismisses Peace Effort." April 2, 2009.

http://www.nytimes.com/2009/04/02/world/middleeast/02mideast.html? $r=1 \& s c p=2 \&$ sq=lieberman\&st=cse

"Security Council overwhelmingly calls for immediate Gaza ceasefire." UN News Center. January 8, 2009.

http://www.un.org/apps/news/story.asp?NewsID=29495\&Cr=gaza\&Cr1=

"UN chief wants Gaza conflict halt" BBC News Online. January 13, 2009.

http://news.bbc.co.uk/1/hi/world/middle east/7825480.stm

Zakaria, Fareed. CNN GPS. “Crisis in Gaza."Aired January 11, 2009 http://transcripts.cnn.com/TRANSCRIPTS/0901/11/fzgps.01.html

"Billions Pledged to Rebuild Gaza." BBC News Online. March 2, 2009. http://news.bbc.co.uk/1/hi/world/middle east/7918105.stm

Gaza: UN Official reports horrific hospital scenes of casualties. January 12, 2009 http://www. un.org/apps/news/story.asp?NewsID=29520\&Cr=gaza\&Cr1=unrwa

\section{Endnotes}

1 "Security Council overwhelmingly calls for immediate Gaza ceasefire." UN News Center. January 8, 2009. http://www.un.org/apps/news/story.asp?NewsID=29495\&Cr=gaza\&Cr1=

2 Ravid, Barak and Shamir, Shlomo. “Israel Rejects UN Truce Resolution." Haaretz Correspondents and New Agencies. January 10, 2009. http://www.haaretz.com/hasen/spages/1054201.html

3 Gaza: UN Official reports horrific hospital scenes of casualties. January 12, 2009 http://www. un.org/apps/news/story.asp?NewsID=29520\&Cr=gaza\&Cr1=unrwa

4 Maqbool, Aleem. "Scale of Gaza Destruction Emerges." January 19, 2009. http://news.bbc.co.uk/1/hi/world/middle east/7836869.stm

5 "Billions Pledged to Rebuild Gaza." BBC News Online. March 2, 2009. http://news.bbc.co.uk/1/hi/world/middle_east/7918105.stm

Haass, Richard and Indyk, Martin. "Beyond Iraq: A New U.S. Strategy for the Middle East." Foreign Affairs. January/February 2009.

7 Haass, Richard and Indyk, Martin. "Beyond Iraq: A New U.S. Strategy for the Middle East." Foreign Affairs. January/February 2009.

8 Hanelt, Christian-Peter. "After Gaza: A Common Dialogue Platform for the Middle East." Central and Eastern

European Online Library. Spotlight Europe, Issue: 02 / 2009, pgs: 18, www.ceeol.com.

9 Gause, Gregory III. "The Return of the Old Middle East: How to Win at Balance-of-Power Politics." March 12, 2009 http:// www.foreignaffairs.com/articles/64844/f-gregory-gause-iii/the-return-of-the-old-middle-east?page=show\#

10 "New Israeli Foreign Minister Dismisses Peace Effort." April 2, 2009.

http://www.nytimes.com/2009/04/02/world/middleeast/02mideast.html?_r=1\&scp=2\&sq=lieberman\&st=cse

11 Cordesman, Anthony. "The Gaza War: A Strategic Analysis." Center for Strategic and International Studies: Washington DC. February 2, 2009.

12 Haass, Richard and Indyk, Martin. "Beyond Iraq: A New U.S. Strategy for the Middle East." Foreign Affairs. January/February 2009

Photo Courtesy of:

Kai, Gin." Israeli Prime Minister Ehud Omert, left, President George W. Bush, and Palestinian President Mahmoud Abbas shake hands following President Bush's address." 27 November 2008 U.S. Navy. 6 April 2009.< http://www.navy.mil/view_single.asp?id=53143> 